DOE/NV/11508-14

UC-703

\title{
REVIEW OF ENCAPSULATION TECHNOLOGIES
}

\author{
prepared by
}

Lynn Shaulis

submitted to

Nevada Operations Office

U.S. Department of Energy

RECEIVISD

MAP 181997

OSTI

September 1996

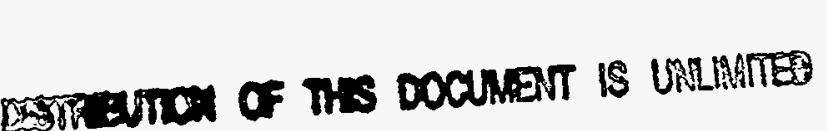
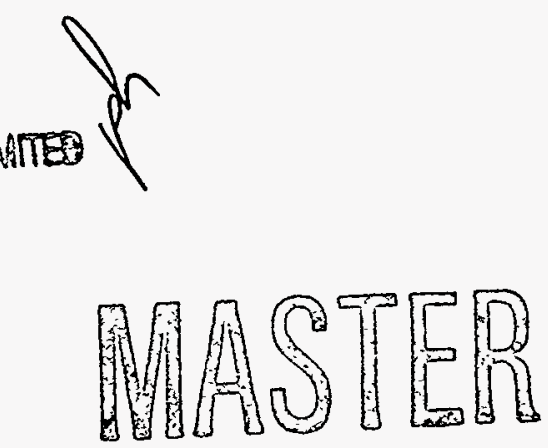

Publication No. 45146 


\section{DISCLA MIIR}

Portions of this document may be illegible: in electronic-image-products: Images are produced from the best available original document. 
This report was prepared as an account of work sponsored by the United States Government. Neither the United States nor the United States Department of Energy, nor any of their employees, makes any warranty, express or implied, or assumes any legal liability or responsibility for the accuracy, completeness or usefulness of any information, apparatus, product or process disclosed, or represents that its use would not infringe privately owned rights. Reference herein to any specific commercial product, process, or service by trade name, mark, manufacturer, or otherwise, does not necessarily constitute or imply its endorsement, recommendation, or favoring by the United States Government or any agency thereof. The views and opinions of authors expressed herein do not necessarily state or reflect those of the United States Government or any agency thereof.

This report has been reproduced directly from the best available copy.

Available to DOE and DOE contractors from the Office of Scientific and Technical Information, P.O. Box 62, Oak Ridge, TN 37831; prices available from (423) 576-8401.

Available to the public from the National Technical Information Service, U.S. Department of Commerce, 5285 Port Royal Rd., Springfield, VA 22161. 


\title{
REVIEW OF ENCAPSULATION TECHNOLOGIES
}

\author{
prepared by \\ Lynn Shaulis \\ Biological Sciences Center \\ Desert Research Institute \\ University and Community College System of Nevada
}

Publication No. 45146

submitted to

Nevada Operations Office

U.S. Department of Energy

Las Vegas, Nevada

September 1996

The work upon which this report is based was supported by the U.S. Department of Energy under Contract \#DE-AC08-95NV11508. 


\begin{abstract}
The use of encapsulation technology to produce a compliant waste form is an outgrowth from existing polymer industry technology and applications. During the past 12 years, the Department of Energy (DOE) has been researching the use of this technology to treat mixed wastes (i.e., containing hazardous and radioactive wastes). The two primary encapsulation techniques are microencapsulation and macroencapsulation. Microencapsulation is the thorough mixing of a binding agent with a powdered waste, such as incinerator ash. Macroencapsulation coats the surface of bulk wastes, such as lead debris.

Cement, modified cement, and polyethylene are the binding agents which have been researched the most. Cement and modified cement have been the most commonly used binding agents to date. However, recent research conducted by DOE laboratories have shown that polyethylene is more durable and cost effective than cements. The compressive strength, leachability, resistance to chemical degradation, etc., of polyethylene is significantly greater than that of cement and modified cement. Because higher waste loads can be used with polyethylene encapsulant, the total cost of polyethylene encapsulation is significantly less costly than cement treatment.

The only research lacking in the assessment of polyethylene encapsulation treatment for mixed wastes is pilot and full-scale testing with actual waste materials. To date, only simulated wastes have been tested. The Rocky Flats Environmental Technology Site had planned to conduct pilot studies using actual wastes during 1996. This experiment should provide similar results to the previous tests that used simulated wastes. If this hypothesis is validated as anticipated, it will be clear that polyethylene encapsulation should be pursued by DOE to produce compliant waste forms.
\end{abstract}




\section{ACKNOWLEDGEMENTS}

This report would not be possible without the financial funding irom DOE Contract \#DE-AC08-95NV11508. Dr. Andrea Faucette of the Rocky Flats Environmental Technology Site, Dr. Peter Kalb of the Brookhaven National Laboratory, and Dr. Aran Armstrong and Mr. Jay Roche of the Idaho National Engineering Laboratory are gratefully acknowledged for their contributions of publications and information on encapsulation technology. 


\section{CONTENTS}

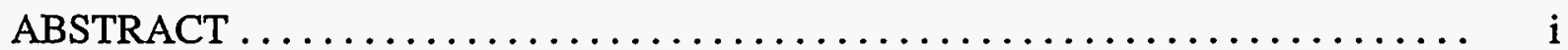

ACKNOWLEDGEMENTS $\ldots \ldots \ldots \ldots \ldots \ldots \ldots \ldots \ldots \ldots \ldots \ldots \ldots \ldots \ldots \ldots \ldots$ ii

LIST OF FIGURES $\ldots \ldots \ldots \ldots \ldots \ldots \ldots \ldots \ldots \ldots \ldots \ldots \ldots \ldots \ldots \ldots \ldots \ldots$ iv

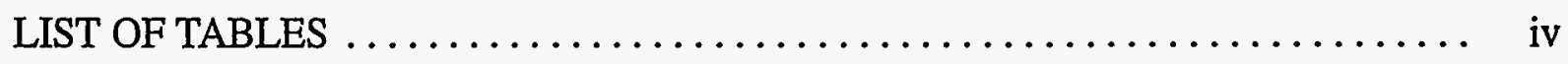

INTRODUCTION $\ldots \ldots \ldots \ldots \ldots \ldots \ldots \ldots \ldots \ldots \ldots \ldots \ldots \ldots \ldots \ldots \ldots \ldots \ldots \ldots$

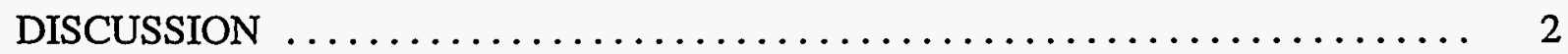

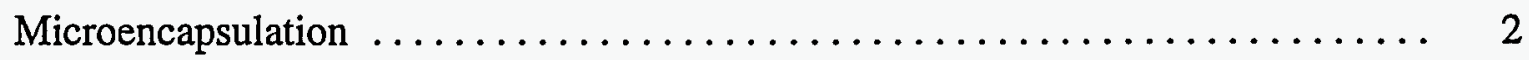

Waste-binder Compatibility ............................ 8

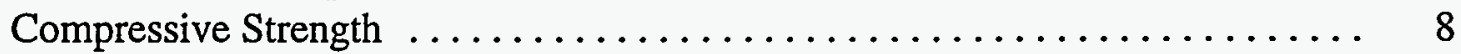

Water Immersion Testing $\ldots \ldots \ldots \ldots \ldots \ldots \ldots \ldots \ldots \ldots \ldots \ldots \ldots, 8$

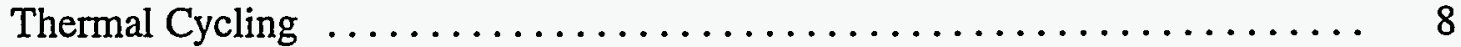

Biodegradation ................................ 9

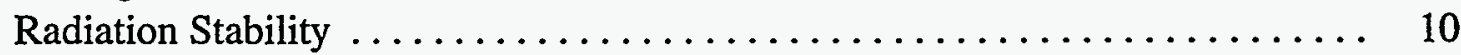

Leachability of Radioactive Constituents $\ldots \ldots \ldots \ldots \ldots \ldots \ldots \ldots \ldots, 10$

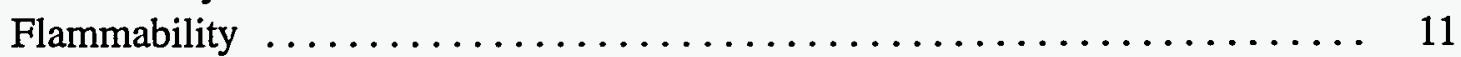

Environmental Stress Cracking and Photodegradation $\ldots \ldots \ldots \ldots \ldots \ldots, 12$

Microencapsulation Treatment Facilities ....................... 12

Macroencapsulation .............................. 12

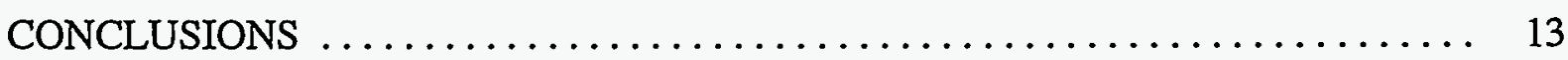

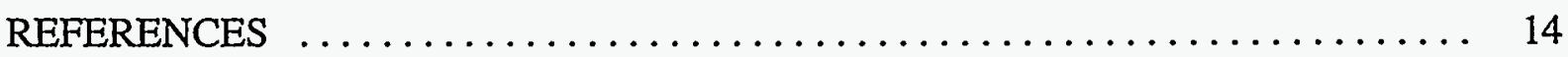

APPENDIX A: $\begin{aligned} & \text { The Application of Polyethylene Resins in Various } \\ & \text { Chemical Environments ............................ } 16\end{aligned}$ 


\section{FIGURES}

1. A flow diagram of the microencapsulation process. ................ 2

2a. A comparative cost breakdown to encapsulate $1 \times 106 \mathrm{~kg}(2.2 \times 106 \mathrm{lbs})$ of nitrate salt per year at Rocky Flats Plant using polyethylene and cement formulations from Savannah River Plant (S.P.) and West Valley (W.V.).

$2 b$. The maximum waste loadings of various wastes encapsulated in cement and polyethylene.

3. Waste loadings comparison of incinerator ash encapsulated in modified sulfur cement (MSC) and portland cement.

4. Compressive yield strength of polyethylene waste forms containing sodium nitrate salt, untreated and after 90 days in water immersion.

\section{TABLES}

1. Results from TCLP tests on INEL incinerator fly ash encapsulated in modified

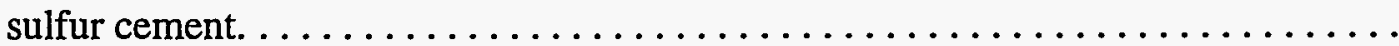

2. Changes in polyethylene properties with density, melt index, and molecular-weight distribution.

3. Compressive yield strength of cored pilot-scale polyethylene waste forms containing $60 \mathrm{wt} \%$ sodium nitrate.

4. Results from the EPA TCLP for Rocky Flat Plant (RFP) nitrate salt encapsulated in polyethylene.

5. Projected cumulative fraction leached (CFL) and diffusions rates (De) after 300 years of leaching for full-scale polyethylene waste forms containing nitrate salt wastes.

6. Polymer microencapsulation treatment systems (from Roach, 1996). ........ 12

7. Polymer macroencapsulation treatment systems (from Roach, 1996). ........ 13 


\section{INTRODUCTION}

This report will review micro- and macro-encapsulation technologies and their potential effectiveness to produce storage-compliant wastes. The information in this report was derived from several reports and articles prepared by scientists at the Brookhaven National Laboratory (BNL), Rocky Flats Environmental Technology Site (RFETS), and Idaho National Engineering Laboratory (INEL). The Department of Energy (DOE) is interested in using this technology to store low-level mixed wastes, and over the past 12 years has been supporting the development of encapsulation treatment (Faucette, 1996). Polymer encapsulation has been proposed as the process to produce Resource Conservation and Recovery Act (RCRA)-compliant waste forms for several mixed wastes at RFETS (Armentrout and Faucette, 1996). RFETS has therefore conducted a fair amount of research on encapsulation technology. BNL has also conducted research on encapsulation technology and its application to DOE waste streams. In particular, BNL has examined polyethylene and modified sulfur cement encapsulation while RFETS has focussed on polymer encapsulation.

Encapsulation is a process that coats waste materials in a manner that permits safe storage of the waste. If the waste to be encapsulated contains hazardous or mixed wastes, then the resulting encapsulated product must meet federal (RCRA) and state requirements for storage of these substances. Typically, this means that the encapsulating material must be resistant to leaching and degradation by the contaminants which will be in contact with the encapsulant ( 40 CFR 268.45). The DOE laboratories that have been testing this technology have not only tested encapsulants for leachability and chemical degradation, they have also tested some encapsulants for: biodegradation; tolerance to irradiation; environmental stress cracking; photodegradation; flammability; compressive strength; and ability to tolerate thermal cycling (Kalb and Colombo, 1984; Kalb et al., 1991b; Kalb et al., 1993). These tests have also shown that encapsulation is an appropriate treatment technology for mixed waste streams including: evaporator concentrate salts, sludges, incinerator ash, ion exchange resins, blowdown solutions, and molten salt oxidation residuals. Additionally macroencapsulation has been proven as an effective treatment of radioactive lead and debris wastes.

Materials that are used as encapsulating agents include cement, modified cement, and two classes of polymers, namely, thermosetting and thermoplastic. Thermosetting polymers, e.g., epoxies, are the product of the chemical reaction between a liquid monomer and a curing agent. They are used to encapsulate powdered waste by mixing the waste with the two thermosetting substances. One of the significant problems with thermosetting encapsulation is the possibility of the waste chemically reacting with the thermosetting agents and thereby preventing solidification (Faucette, 1996). However, thermosetting polymers may successfully be used for macroencapsulation of wastes. Thermoplastic polymers, e.g., polyethylene, are heated above their melting point temperature $\left(110^{\circ} \mathrm{C}\right)$ then mixed with powdered waste and poured into a disposal container for cooling and hardening. Because this temperature is sufficiently low, no off-gas treatment is required and no secondary wastes are produced (Faucette, 1996). The following text will discuss microencapsulation and macroencapsulation in more detail. This discussion will describe the processes, types of encapsulants, and the potential durability of the encapsulated products. 


\section{DISCUSSION}

\section{Microencapsulation}

Microencapsulation is a process that thoroughly mixes fine waste particles with an encapsulant prior to or during extrusion (see Figure 1). According to RCRA 40 CFR 268.45, microencapsulation is an alternative treatment standard for hazardous waste, but must produce a final waste that meets the RCRA Toxicity Characteristic Leaching Procedure (TCLP) concentration limits, Method 1311 of EPA Publication SW-846 (Roach, 1996). Microencapsulating materials primarily include cement/grout and polymers. Common cements and grouts, such as Portland cement, are typically considered to be less expensive than polymer encapsulants (at $20 \mathrm{tons} / \mathrm{hr}$, polyethylene would cost $\$ 95$ to $\$ 112$ per ton of waste ash treated versus $\$ 50$ to $\$ 60$ per ton for cement; Faucette, 1996). However, if all operation costs are considered, specifically storage, shipping and disposal, then polymer microencapsulation is significantly more cost effective than cement $\left(\$ 18,744 / \mathrm{m}^{3}\right.$ for polymer encapsulation versus $\$ 65,707 / \mathrm{m}^{3}$ for cement; Faucette, 1996). The primary reason that polymer encapsulation is more cost effective when all processes are considered is due to the fact that polymers have a higher waste loading (i.e., more waste per unit encapsulant)

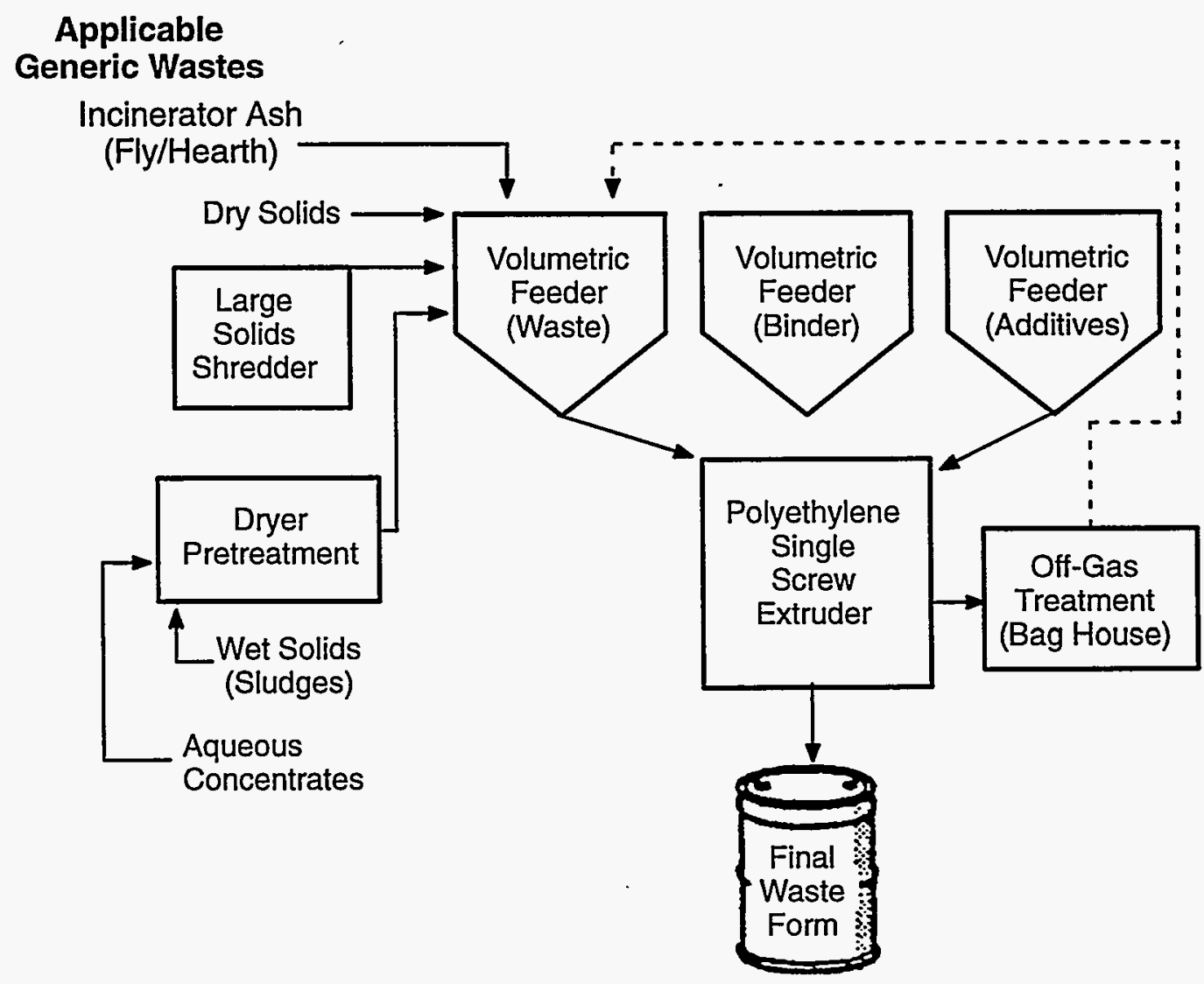

Figure 1. A flow diagram of the microencapsulation process (from Kalb, 1993). 
than cement which results in a significantly reduced waste product volume. Figure 2a depicts a cost breakdown and comparison for polyethylene and concrete encapsulation. Figure $2 b$ depicts the maximum waste loadings for the two different encapsulants. However, polymer encapsulation is not amenable to wastes which contain greater than $2 \%$ by weight moisture or volatile organic content. This is due to the fact that the heat generated during waste/polymer mixing can produce
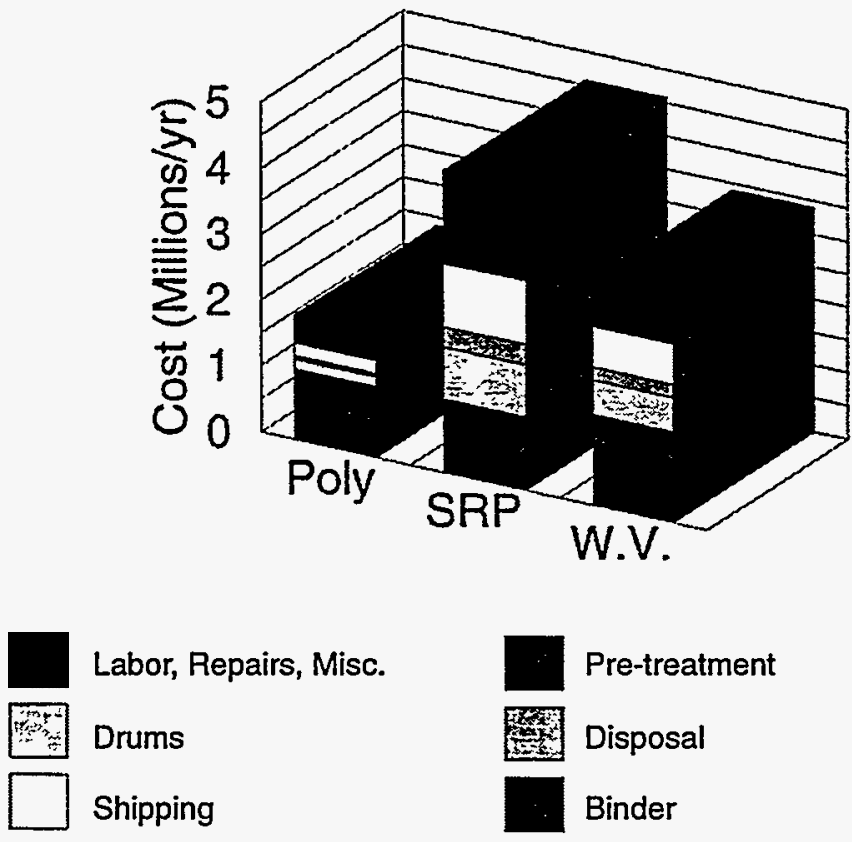

Figure 2a. A comparative cost breakdown to encapsulate $1 \times 10^{6} \mathrm{~kg}\left(2.2 \times 10^{6} \mathrm{lbs}\right)$ of nitrate salt per year at Rocky Flats Plant using polyethylene and cement formulations from Savannah River Plant (S.P.) and West Valley (W.V.) (from Kalb et al., 1991b).

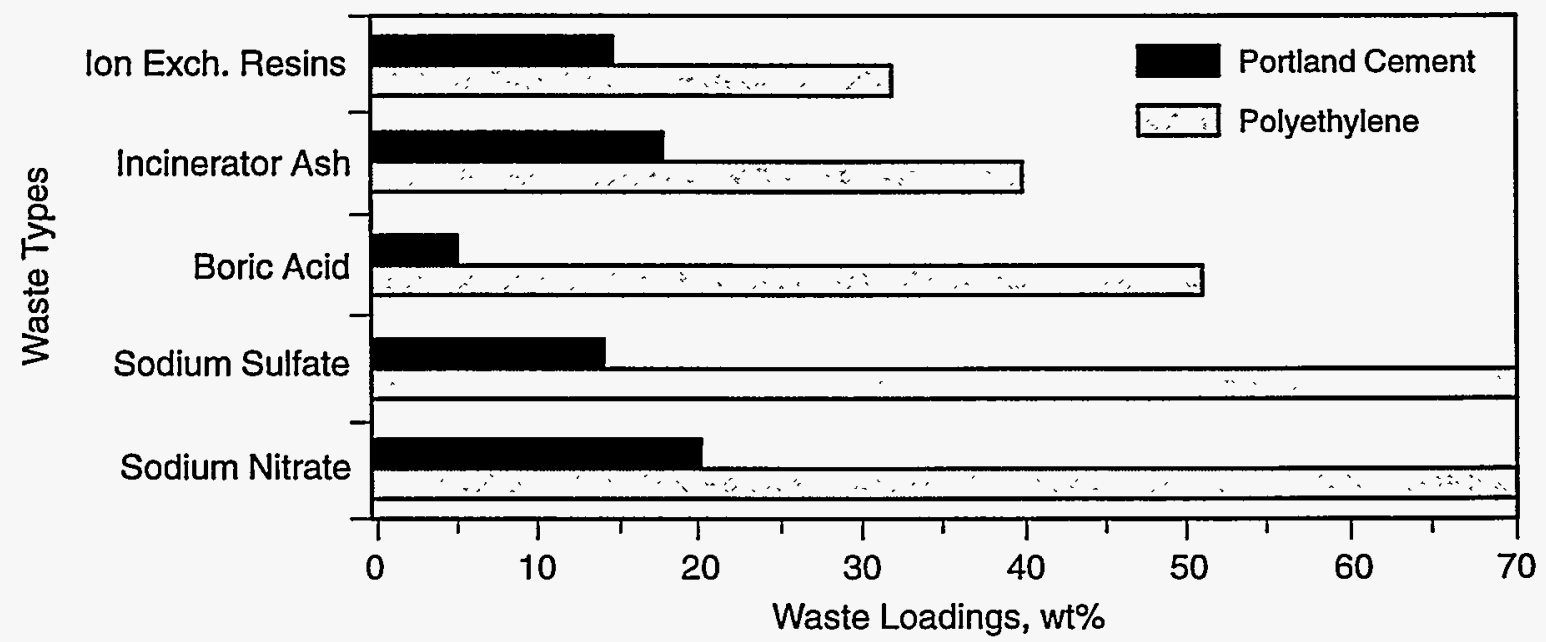

Figure 2b. The maximum waste loadings of various wastes encapsulated in cement and polyethylene (from Kalb, 1993). 
vaporization/volatilization of the water/organic in the waste. Pre-encapsulation treatments, such as drying, can yield waste streams that are amenable to encapsulation.

\section{Modified Cement Encapsulation}

Some waste streams contain soluble metal salts which form acids when exposed to moisture. An acidic environment can prevent solidification of cements leading to a reduction in mechanical strength and increased mobility of contaminants. Kalb et al. (1991a) investigated the efficacy of a modified sulfur cement as an encapsulant for INEL mixed-waste-contaminated incinerator ash that contained metal chloride salts, primarily zinc chloride. "Modified sulfur cement is a thermoplastic material that can be easily melted, combined with waste components in a homogeneous mixture, and cooled to form a solid monolithic waste form" (Kalb et al., 1991a). Sulfur cements have several advantages over common hydraulic cements (e.g., portland cement), namely: solidification does not require any chemical reaction; compressive and tensile strengths are twice those of portland cements; and sulfur cements are resistant to degradation by most acids and salts (Kalb et al., 1991a).

The U.S. Bureau of Mines developed modified sulfur cement in 1972 to utilize the sulfur by-product from flue gas and petroleum distillation processes. Elemental sulfur is reacted with hydrocarbon polymers that yield a product that suppresses solid-phase transformation and therefore improves material stability (Kalb et al., 1991a).

Kalb et al. (1991a) tested the leachability of the sulfur cement/waste product using the TCLP. The results of this test showed that the leachate contained cadmium $(\mathrm{Cd})$ and lead $(\mathrm{Pb})$ contents well above the $1.0 \mathrm{mg} / \mathrm{L} \mathrm{Cd}$ and $5.0 \mathrm{mg} / \mathrm{L} \mathrm{Pb}$ allowed by EPA (i.e., leachate $\mathrm{Cd}$ and $\mathrm{Pb}$ contents were $85 \mathrm{mg} / \mathrm{L}$ and $46 \mathrm{mg} / \mathrm{L}$, respectively). Therefore, Kalb et al. investigated several potential additives that would reduce the mobility of heavy metals in the incinerator ash waste. Sodium sulfide $\left(\mathrm{Na}_{2} \mathrm{~S}\right)$ was selected for use as an additive because it reacts with metal salts to form metal sulfides which have an extremely low solubility. TCLP tests were conducted on the modified sulfur cement plus additive waste product and the metal content of the leachates were well below EPA allowable contents. Table 1 lists the results of the TCLP test. Figure 3 depicts how use of modified sulfur cement and $\mathrm{Na}_{2} \mathrm{~S}$ results in a higher waste loading than common cement.

\section{Polymer Encapsulation}

There are two general groups of polymers, thermoplastic and thermosetting. Because thermoset polymers require reaction between a liquid monomer and curing agent, some waste components react with the monomer and curing agent thus interfering with solidification (Faucette, 1996). Therefore, thermoset polymers are better suited to macroencapsulation. Another consideration is the relatively high cost of thermoset resins. Thermoplastic polymers (such as polyethylene) are heated above their melting point $\left(110^{\circ} \mathrm{C}\right)$ and mixed with powdered wastes. The molten mixture is poured into disposal containers (e.g., 55-gallon drums) where solidification occurs as the mixture cools (Faucette, 1996). Most chemicals do not react with polyethylene and therefore polyethylene is well suited for microencapsulation. In addition, polyethylene may be derived from recycled plastics, a cost-effective and environmentally efficient approach to encapsulation. 
TABLE 1. RESULTS FROM TCLP TESTS ON INEL INCINERATOR FLY ASHENCAPSULATED IN MODIFIED SULFUR CEMENT (from Kalb et al., 1991).

\begin{tabular}{lcc}
\hline \multicolumn{1}{c}{ Sample Tested } & \multicolumn{3}{c}{ Concentrations of Criteria } \\
Metals, $\mathrm{mg} / \mathrm{L}^{\mathrm{a}}$ & $\mathrm{Pb}$ \\
\hline INEL Fly Ash & 46.0 & 85.0 \\
$55 \mathrm{wt} \%$ Ash & & $17.6(32.0)$ \\
$45 \mathrm{wt} \% \mathrm{MSC}$ & $27.5(50.0)$ & $12.0(30.0)$ \\
$40 \mathrm{wt} \%$ Ash & & \\
$60 \mathrm{wt} \% \mathrm{MSC}$ & $13.6(34.0)$ & $1.0(2.5)$ \\
$40 \mathrm{wt} \%$ Ash & & \\
$53 \mathrm{wt} \% \mathrm{MSC}$ & & \\
$7 \mathrm{wt} \% \mathrm{Na}$ S & $0.1(0.3)$ & $1.5(3.5)$ \\
$43 \mathrm{wt} \%$ Ash & & 5.0 \\
$50 \mathrm{wt} \% \mathrm{MSC}$ & & \\
7 wt\% Na S & $0.2(0.5)$ & \\
EPA Allowable Limit & 1.0 & \\
\hline
\end{tabular}

aData in parentheses represent concentrations normalized to account for reduced mass of fly ash in sample tested.

${ }^{\mathrm{B}} \mathrm{MSC}=$ modified sulfur cement

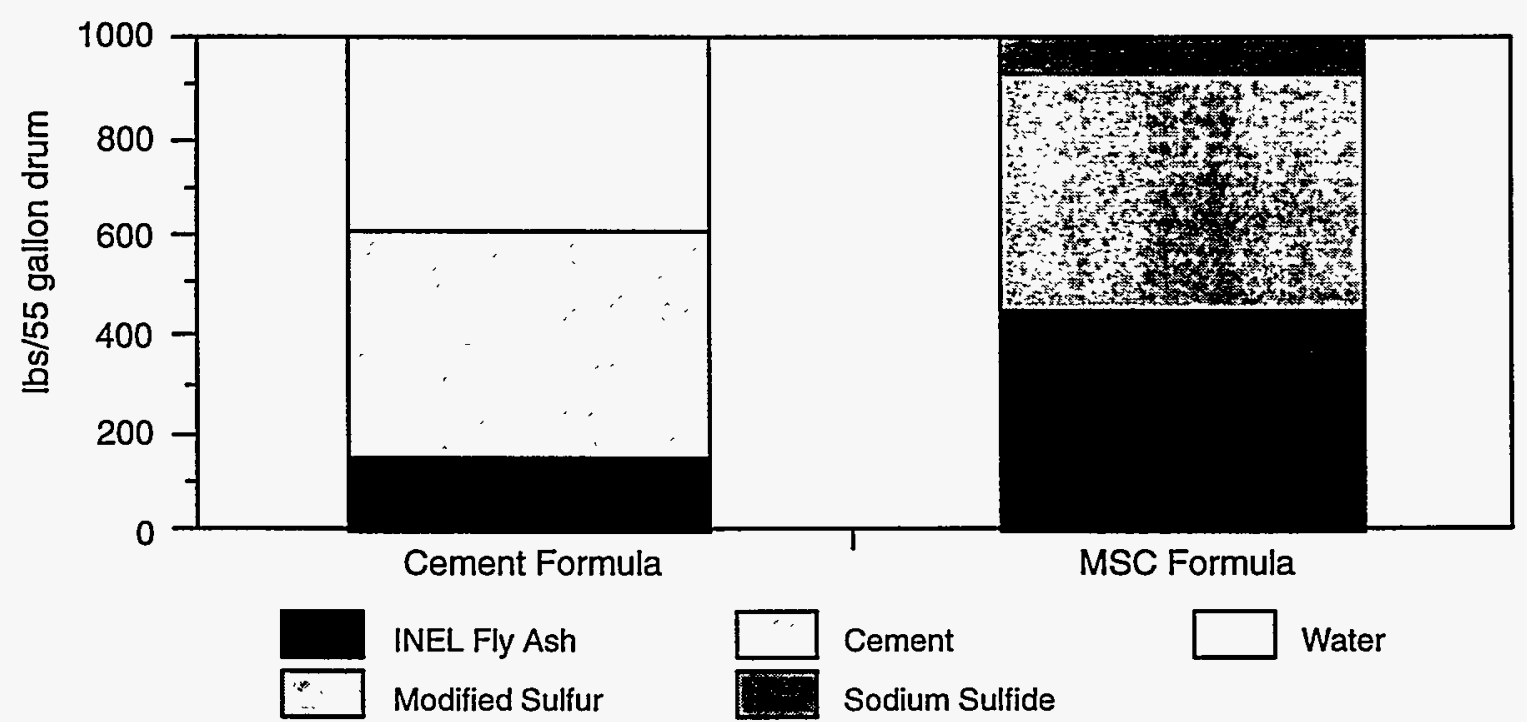

Figure 3. Waste loadings comparison of incinerator ash encapsulated in modified sulfur cement (MSC) and portland cement (from Kalb et al., 1991a). 
Studies completed to date indicate that waste loadings of 30 to $80 \mathrm{wt} \%$ are possible with polyethylene extrusion. Waste loadings of $50 \mathrm{wt} \%$ are typical for most mixed wastes that have been tested (Faucette, 1996). Kalb et al. (1993) state that polyethylene encapsulation can accommodate up to $70 \mathrm{wt} \%$ nitrate salt waste compared to 13 to $20 \mathrm{wt} \%$ when portland cement is used as the encapsulant. Faucette (1996) states that polymer encapsulation provides increased waste loadings, i.e., more waste by wt\% can be encapsulated with polyethylene than cement, increased encapsulation product durability, and is rather insensitive to variations in waste stream chemistry in comparison to common cement. While the polyethylene microencapsulation process is resistant to most chemicals, it is sensitive to moisture content. If wastes contain more than 3 to $10 \%$ moisture, a drying procedure must be performed prior to polyethylene extrusion.

Polyethylene is a thermoplastic polymer that has been researched more extensively than any other thermoplastic polymer by DOE laboratories. Therefore, this discussion is limited to polyethylene. "Polyethylene is an organic polymer material of crystalline-amorphous structure, formed through the polymerization of ethylene gas" (Kalb et al., 1991b). By controlling the design of polyethylene's molecular structure, hundreds of compound variations with differing properties may be produced. These variations are produced by manipulating process parameters and selecting particular additives, and are characterized by the degree of crystallinity (Kalb et al., 1991b). The degree of crystallinity determines the density of a particular polyethylene, which affects a number of material properties, as listed in Table 2. In addition, the melt index (a measure of viscosity or the ease with which molten polyethylene flows) and molecular weight (an average of all polymer chains produced during polymerization) affect the properties of polyethylene. Polyethylenes with high molecular weights tend to be tougher and are more resistant to stress cracking and harsh chemicals than low molecular weight polyethylene. However, they are more difficult to process; therefore, a narrow molecular weight distribution (2.5:1 to $18: 1)$ provides a balance between process ease and optimal mechanical properties (Kalb et al., 1991b).

TABLE 2. CHANGES IN POLYETHYLENE PROPERTIES WITH DENSITY, MELT INDEX, AND MOLECULAR-WEIGHT DISTRIBUTIONa,b (from Kalb et al., 1991b).

\begin{tabular}{lccc}
\hline \hline \multicolumn{1}{c}{ Property } & $\begin{array}{c}\text { As Density } \\
\text { Increases }\end{array}$ & $\begin{array}{c}\text { As Melt } \\
\text { Index Increases }\end{array}$ & $\begin{array}{c}\text { As Molecular Weight } \\
\text { Distribution Increases }\end{array}$ \\
\hline Abrasion resistance & + & - & \\
Blocking resistance & + & - & - \\
Brittleness resistance & - & - & - \\
Brittleness temp & - & + & + \\
Chemical resistance & + & - & + \\
Cold flow resistance & + & - & - \\
Hardness & + & $-(\mathrm{sl})$ & + \\
Impact strength & - & - & + \\
Load-bearing properties, long-term & + & - & \\
Melt elasticity & & - & \\
Melt viscosity & & - & \\
\hline
\end{tabular}


TABLE 2. CHANGES IN POLYETHYLENE PROPERTIES WITH DENSITY, MELT INDEX, AND MOLECULAR-WEIGHT DISTRIBUTION ${ }^{\mathrm{a}, \mathrm{b}}$ (from Kalb et al., 1991b) (Continued).

\begin{tabular}{lccc}
\hline \hline \multicolumn{1}{c}{ Property } & $\begin{array}{c}\text { As Density } \\
\text { Increases }\end{array}$ & $\begin{array}{c}\text { As Melt } \\
\text { Index Increases }\end{array}$ & $\begin{array}{c}\text { As Molecular Weight } \\
\text { Distribution Increases }\end{array}$ \\
\hline Mold shrinkage & - & - & \\
Permeability & - & $+(\mathrm{sl})$ & + \\
Softening point & + & & \\
Specific heat & $-(\mathrm{sl})$ & $-(\mathrm{sl})$ & \\
Stiffness & + & - & - \\
Stress-cracking resistance & - & - & \\
Tensile elongation at break & - & $-(\mathrm{sl})$ & \\
Tensile modulus & + & - & \\
Tensile strength at break & + & $-(\mathrm{sl})$ & \\
Tensile yield stress & + & & \\
Thermal conductivity & + & & \\
Thermal expansion & - & & \\
a + denotes increase: - denotes decrease; sl denotes a slight change & &
\end{tabular}

By controlling the polymerization process pressure, low-density polyethylene (LDPE) or high-density polyethylene (HDPE) may be produced. LDPEs (densities ranging from 0.910- 0.925 $\mathrm{g} / \mathrm{cm}^{3}$ ) result from high-process pressures which produce a large number of polymer branches. HDPEs (densities ranging from $0.941-0.959 \mathrm{~g} / \mathrm{cm}^{3}$ ) are formed under low-process pressures that give rise to long linear chains of polymerized ethylene. Medium-density polyethylenes ( 0.926 $0.940 \mathrm{~g} / \mathrm{cm}^{3}$ ) can be produced either by adjusting process pressures or mixing LDPE and HDPE materials. Although Table 2 indicates that higher-density polyethylenes have greater mechanical strengths and are more resistant to harsh chemicals, LDPE is more favorable because its increased branching results in a greater resistance to biodegradation (Kalb et al., 1991b). BNL uses LDPE for its encapsulation process because it does not require high temperatures and pressures and it is therefore more cost effective than HDPE (Kalb et al., 1991b).

As stated previously, various waste streams have been used to test encapsulation processes. In particular, polyethylene microencapsulation has been shown to be an effective treatment approach for evaporator concentrate salts, sludges, incinerator ash, and ion exchange resins, all of which may contain mixed wastes (i.e., radiation and toxic heavy metals). Table A-1 in Appendix A lists the various chemicals for which polyethylene may be used. This list clearly shows that there are very few chemicals for which polyethylene would be an inappropriate encapsulating material with a major exception of various oils and gasoline.

Several studies have been performed by DOE laboratories to evaluate encapsulated waste form performances. The primary goals of these studies were to:

- provide input data for modeling disposal site performance 
- estimate long-term durability of waste forms

- demonstrate compliance with existing environmental regulations

- examine potential synergistic effects of waste-binder interactions on performance and durability

- compare performance among potential binder materials" (from Kalb et al., 1991)

The tests performed by Kalb et al. (1991) used laboratory and pilot-scale waste materials containing simulated sodium nitrate salt or actual nitrate salt waste from Rocky Flats. Other studies performing similar tests on sodium sulfate, boric acid, incinerator ash and ion exchange resins were cited by Kalb et al., i.e., Kalb and Colombo, 1984; Franz and Colombo, 1984; Franz et al., 1987; and Heiser et al., 1989.

\section{Waste-binder Compatibility}

Waste streams of more than $5 \%$ nitrate salt compositions were tested with polyethylene at temperatures up to $400^{\circ} \mathrm{C}$ (three times higher than the standard processing temperature of $120^{\circ} \mathrm{C}$ ). Several thermograms obtained by differential scanning calorimetry were obtained. The only peaks observable in these thermograms were characteristic endotherms corresponding to melting points or crystal transitions of the materials. The absence of exothermic peaks at temperatures up to $400^{\circ} \mathrm{C}$ is indicative of the thermal stability of the polyethylene/nitrate salt waste mixtures.

\section{Compressive Strength}

Compressive strength was tested to show the ability of the encapsulated waste to withstand loading pressures common with stacking of waste forms and burial under soil or barrier materials. ASTM D-695, the Standard Method of Test for Compressive Properties of Rigid Plastics, was used to test the waste form strength. The compressive yield strength was shown to vary with waste loading, from 7.03 MPa for $70 \mathrm{wt} \%$ sodium nitrate to $16.3 \mathrm{MPa}$ for $30 \mathrm{wt} \%$ sodium nitrate. These results were well above the minimum $0.41 \mathrm{MPa}$ Nuclear Regulatory Commission (NRC) strength criteria. Figure 4 shows the compressive strength of various wt $\%$ sodium nitrate untreated and after 90 days of water immersion.

\section{Water Immersion Testing}

The polyethylene encapsulated waste forms were immersed in water for 90 days and then tested for compressive strength as stated above. Figure 4 depicts the results of this test and clearly shows that in general no loss of compressive yield strength was observed. Only the $70 \mathrm{wt} \%$ sodium nitrate salt waste form exhibited an approximate $30 \%$ reduction in compressive strength. However, all samples still exceeded the minimum compressive strength criteria by at least one order of magnitude (Kalb et al., 1991b).

\section{Thermal Cycling}

The thermal cycling tests were conducted according to ASTMB-553, Standard Method of Test for Thermal Cycling of Electroplated Plastics. "Cored specimens from the pilot-scale waste form 


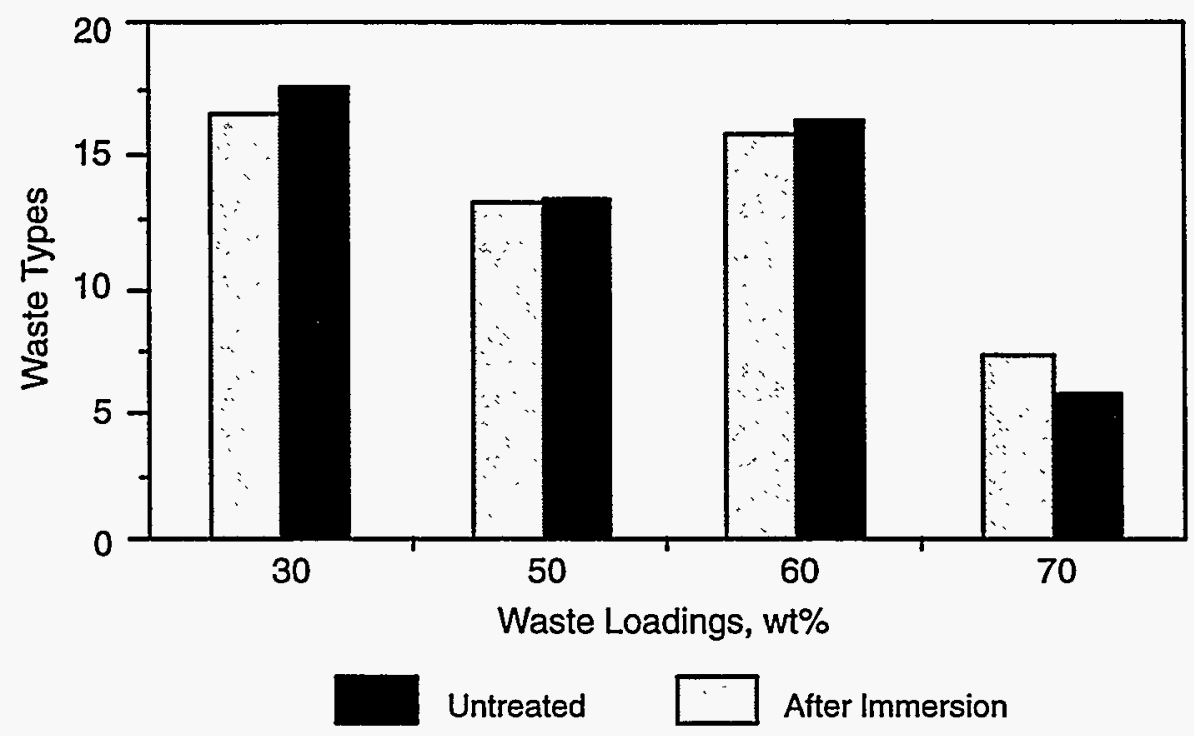

Figure 4. Compressive yield strength of polyethylene waste forms containing sodium nitrate salt, untreated and after 90 days in water immersion (from Kalb et al., 1991b).

were cycled between temperature extremes of $-40^{\circ} \mathrm{C}$ and $+60^{\circ} \mathrm{C}$ for a total of 30 , five-hour periods" (Kalb et al., 1991b). Table 3 lists the results of this test and indicates that no statistically significant changes in compressive yield strength were produced by the thermal cycling.

TABLE 3. COMPRESSIVE YIELD STRENGTH OF CORED PILOT-SCALE POLYETHYLENE WASTE FORMS CONTAINING 60 WT\% SODIUM NITRATE (from Kalb et al., 1991b).

\begin{tabular}{lc}
\hline \hline Test Description & Compressive Yield Strength, Mpa \\
\hline Initial & $14.2 \pm 0.3$ \\
Post Thermal Cycling & $13.3 \pm 0.5$ \\
Post Irradiation & $16.7 \pm 0.7$ \\
Post Biodegradation & $10.1 \pm 1.8$ \\
\hline
\end{tabular}

Biodegradation

A literature review conducted by Kalb et al. (1991b) indicated that polyethylene is not susceptible to biodegradation, particularly LDPE. Testing of polyethylene waste forms containing sodium sulfate, boric acid, incinerator ash, and ion exchange resin resulted in no growth of microorganisms (Franz and Colombo, 1984). The tests were performed according to ASTM G-21, Standard Practice for Determining Resistance of Plastics to Bacteria. In addition to pilot-scale core samples, blank control samples of polyethylene were tested. After 21 days of incubation, no fungal or bacterial growth was observed on any of the samples. However, compressive yield strength tests resulted (see Table 3 ) in a $29 \%$ reduction of strength for the incubated samples (note: the 
compressive yield strength was still above the minimum required). Because no microorganism growth was observed, the decline in compressive yield strength could not have been due to biodegradation. The authors re-examined the samples and found that some solubilization of the nitrate salts had occurred in both the nutrient agar and sterilization solvent. Because the coring process resulted in fresh-cut surfaces, solubilization was accelerated. This would not occur under normal processing conditions.

\section{Radiation Stability}

Pilot-scale core samples of sodium nitrate waste form were exposed to a ${ }^{60} \mathrm{Co}$ gamma source at a dose rate of $3.6 \times 10^{6} \mathrm{rad} / \mathrm{hr}$, for a total dose of $10^{8} \mathrm{rad}$. Irradiation resulted in an $18 \%$ increase in compressive yield strength as indicated in Table 3 . These results confirm the prediction of other studies that irradiation would increase polyethylene strength. Therefore, encapsulation of low-level waste/mixed waste with polyethylene should result in a compliant waste form.

Leachability of Radioactive Constituents

Kalb et al. (1991b) performed the EPA Toxicity Characteristic Leaching Procedure (TCLP) on encapsulated sodium nitrate salt wastes from the Rocky Flats Plant in Colorado. The tests were designed to simulate probable sanitary landfill conditions. In particular, the TCLP requires vigorous agitation. The results of this test are compared with the untreated waste and reported in Table 4. Polyethylene encapsulated wastes were below the EPA leachate allowable limits for the metals reported.

TABLE 4. RESULTS FROM THE EPA TCLP FOR ROCKY FLAT. PLANT (RFP) NITRATE SALT ENCAPSULATED IN POLYETHYLENE (from Kalb et al., 1991b).

\begin{tabular}{lcccc}
\hline \hline & \multicolumn{4}{c}{ Concentration of Criteria Metals, ppm } \\
\cline { 3 - 5 } Sample Tested & $\mathrm{Cr}$ & $\mathrm{Cd}$ & $\mathrm{Pb}$ & $\mathrm{Ba}$ \\
\hline RFP Nitrate Salt & 9.0 & 0.4 & 0.5 & $<0.5$ \\
60 wt\% RFP Salt in LDPE & 3.6 & 0.2 & 0.3 & $<0.5$ \\
EPA Allowable Limit & 5.0 & 1.0 & 5.0 & 100 \\
\hline
\end{tabular}

Kalb and Colombo (1984) prepared simulated radioactive waste containing 10,30 and $50 \mathrm{wt} \%$ sodium sulfate, 25 and $35 \mathrm{wt} \%$ incinerator ash, and ${ }^{137} \mathrm{Cs},{ }^{60} \mathrm{Co}$ and ${ }^{85} \mathrm{Sr}$ tracers. Leaching tests were performed according to the American Nuclear Society (ANS) 16.1 Standard "Measurement of the Leachability of Solidified Low-Level Radioactive Wastes." The samples were leached for 91 days in demineralized water at a temperature of $20 \pm 2^{\circ} \mathrm{C}$. While Kalb and Colombo (1984) do not specify whether the ANS procedure requires agitation, it is highly probable that the ANS procedure is not as conservative as the more recent TCLP. In general, Kalb and Colombo found that all three tracers leached at similar rates with larger amounts of tracers leaching from the higher waste load samples and with increased exposure to the leaching solution. It was also found that higher amounts of tracer leached from the sodium sulfate in comparison to the incinerator ash. The authors 
hypothesized that the highly soluble nature of the sodium sulfate salt resulted in dissolution of the salt and hence an increased porosity within the waste. The solubility of the salt and the increased porosity provided more pathways for tracer migration. Unfortunately, Kalb and Colombo do not provide any information about allowable radioactive leachate amounts and therefore it is not possible to ascertain whether the amounts of tracer measured were environmentally significant or not.

While the Kalb and Colombo (1984) data limit interpretation, a study by Kalb, Fuhrmann and Colombo (1993) provides information that permits long-term assessment of leaching. Kalb, Fuhrmann and Colombo (1993) performed an accelerated leach test (ALT) to model cumulative fractional releases of waste after 300 years of leaching under fully saturated conditions. Table 5 lists the projected releases of wastes treated by polyethylene encapsulation after 300 years of leaching. The only limitation of this model is the assumption that the treated wastes remained structurally stable during that time interval. Their results indicate that approximately $5-17 \%$ of the contaminant source will be leached after 300 years of exposure to saturated conditions. They state that in contrast, portland cement waste forms would release about $17 \%$ of the contaminant source after only 11 years. Therefore, polyethylene binder provides 27 times the leaching longevity as portland cement.

TABLE 5. PROJECTED CUMULATIVE FRACTION LEACHED (CFL) AND DIFFUSIONS RATES $\left(D_{e}\right)$ AFTER 300 YEARS OF LEACHING FOR FULL-SCALE POLYETHYLENE WASTE FORMS $^{\text {a }}$ CONTAINING NITRATE SALT WASTES (from Kalb, Fuhrmann and Colombo, 1993).

\begin{tabular}{ccccccc}
\hline \hline Temp ${ }^{\circ} \mathrm{C}$ & \multicolumn{2}{c}{$50 \mathrm{wt} \%$ Salt } & \multicolumn{2}{c}{$60 \mathrm{wt} \%$ Salt } & \multicolumn{2}{c}{$70 \mathrm{wt} \%$ Salt } \\
& $\mathrm{D}_{\mathrm{e}}\left(\mathrm{cm}^{2} / \mathrm{s}\right)$ & $\mathrm{CFL}(\%)$ & $\mathrm{D}_{\mathrm{e}}\left(\mathrm{cm}^{2} / \mathrm{s}\right)$ & $\mathrm{CFL}(\%)$ & $\mathrm{D}_{\mathrm{e}}\left(\mathrm{cm}^{2} / \mathrm{s}\right)$ & $\mathrm{CFL}(\%)$ \\
\hline 20 & $3.05 \times 10^{-9}$ & 3.7 & $8.6 \times 10^{-9}$ & 5.0 & $5.58 \times 10^{-8}$ & 9.5 \\
35 & $2.65 \times 10^{-9}$ & 3.6 & $1.90 \times 10^{-8}$ & 6.3 & $7.63 \times 10^{-8}$ & 10.7 \\
50 & $5.32 \times 10^{-9}$ & 4.3 & $3.10 \times 10^{-8}$ & 7.6 & $1.34 \times 10^{-7}$ & 13.4 \\
70 & $9.69 \times 10^{-9}$ & 5.1 & $2.40 \times 10^{-8}$ & 6.9 & $2.33 \times 10^{-7}$ & 16.8 \\
\hline
\end{tabular}

aProjected releases for 6.3 cubic meter full-scale waste form ( $2 \mathrm{~m}$ diameter $\times 2 \mathrm{~m}$ in height)

Flammability

Kalb et al. (1993) state that flammability is not a concern for treated wastes after they have been deposited in shallow landfills, because there is not sufficient oxygen available for combustion. However, during the treatment and transportation phases, combustion may occur. Samples of LDPE were tested according to ASTM D-1929 "Standard Method of Test for Ignition Properties of Plastics." The flash ignition temperature for polyethylene was $409^{\circ} \mathrm{C}$ and the self-ignition temperature was $430^{\circ} \mathrm{C}$. Because polyethylene is heated to only $120^{\circ} \mathrm{C}$ for extrusion purposes, it is highly unlikely that a fire will occur during the treatment process. If the polyethylene waste form should be ignited, polyethylene burns slowly in a controlled manner, i.e., $1.0 \mathrm{in} / \mathrm{min}$ (Kalb et al., 1993). 
Environmental Stress Cracking and Photodegradation

Environmental stress cracking of polyethylene may occur under conditions of stress when exposed to soaps, detergents, wetting agents, or oils (Kalb et al., 1993). It is not probable that polyethylene encapsulated waste forms would be exposed to high stress and the above mentioned chemical agents according to Kalb et al. (1993). Deterioration of polyethylene's mechanical properties will occur when exposed to sunlight and oxygen for long periods of time. However, the photodegradation effect would only impact the surface of the waste form, if the wastes were stored in an exposed manner. Because wastes are typically buried in a shallow landfill, photodegradation is not likely to occur (Kalb et al., 1993).

Microencapsulation Treatment Facilities

Table 6 provides a list of microencapsulation treatment system facilities. To date, no polyethylene extrusion processes are permitted for mixed wastes (Faucette, 1996). It is anticipated that this will change as DOE works with private industry to commercialize encapsulation waste treatment.

TABLE 6. POLYMER MICROENCAPSULATION TREATMENT SYSTEMS (from Roach, 1996).

\begin{tabular}{ll}
\hline \hline \multicolumn{1}{c}{ System Name } & \multicolumn{1}{c}{ Site and State } \\
\hline Pantex Mobile Stabilization Skid & Pantex, TX \\
Oak Ridge Commercial Option & Oak Ridge, TN \\
CTMP System 3-LLW Miscellaneous Waste Form Immobilization & RFETS, CO \\
\hline
\end{tabular}

\section{Macroencapsulation}

Macroencapsulation coats bulk wastes such as radioactive lead and debris with an encapsulant. According to 40 CFR 268.42, macroencapsulation is defined as encapsulation "...with surface coating materials such as polymeric organic (e.g., resins and plastics) or with a jacket of inert inorganic materials to substantially reduce surface exposure to potential leaching media." 40 CFR 268.40 states that macroencapsulation is a treatment standard for radioactively contaminated lead solids. Because macroencapsulation is simply the application of a surface coating to a solid rather than mixing with fine particles, macroencapsulation is not governed by as many regulations as microencapsulation. For sleeve-type (i.e., the fusing of a polymer lid onto a polymer sleeve which contains the debris) macroencapsulation, the final waste form must pass the DOT drop tests specified in 49 CFR 173.461 through 465 (Roach, 1996). In addition, containerized waste must not exceed a $10 \%$ void volume according to 40 CFR 264.315 , and any state requirements.

Because the most difficult and abundant DOE waste streams are composed of fine particles which contain mixed wastes, most of the research conducted by the DOE laboratories has focussed on microencapsulation technology. In fact, INEL, BNL and RFETS did not provide any reports or articles that discussed test results for macroencapsulation. However, based on the information provided in the previous microencapsulation section, it is possible to extrapolate test results to macroencapsulated waste forms. 
As stated in the previous section, thermoplastic binders (e.g., polyethylene) meet or exceed all requirements for compression strength, biodegradation, leachability, flammability, irradiation, photodegradation, and chemical interaction. The most important test that would be required of any binding agent used in macroencapsulation would be its ability to resist stress fracturing with weight loading or during transportation. The same will probably hold true for most thermosetting polymers except as noted previously, the resins used for thermosetting polymers can often react with components in the waste debris. The likelihood of chemical interactions with large pieces of waste debris are likely to be reduced in occurrence and effect due the nature of most lead and debris wastes and the decreased surface area in contact with the polymer. It is self evident that polymer encapsulants would have a higher resistance to stress fracture than cements and would be less likely to degrade from saturated conditions or biodegradation. But because the weight loading of macroencapsulation would be the same for cements and polymers, the cost of polymer macroencapsulation would probably be higher. The treatment systems that are presently providing macroencapsulation processing are listed in Table 7.

TABLE 7. POLYMER MACROENCAPSULATION TREATMENT SYSTEMS (from Roach, 1996).

\begin{tabular}{lll}
\hline System Name & Type & Site and State \\
\hline Envirocare of Utah, Inc. & Extrusion & Various \\
WROC Macroencapsulation & Extrusion & INEL, ID \\
Macroencapsulation in a Permitted Containment Building & Extrusion & SRS, SC \\
Commercial Macroencapsulation (was part of WRAP IIA) & Sleeve & Hanford, WA \\
CTMP System 3-LLW Misc Waste Form Immobilization & Extrusion & RFETS, CO \\
Mobile Macroencapsulation & Sleeve & Pantex, TX \\
\hline
\end{tabular}

\section{CONCLUSIONS}

Mixed waste encapsulation treatment using polymers has been adopted by DOE researchers from existing processes developed within the polymer industry. Researchers at BNL and RFETS have performed several tests on the applicability and durability of polymers (predominantly polyethylene) for encapsulation of DOE mixed waste streams. The encapsulation of fine particle waste streams such as incinerator fly ash, evaporator concentrates (e.g., nitrate salt wastes), and ion exchange resins has been one of the primary concerns of the researchers. This is due to the fact that these wastes contain chemical components, such as metals, that increase the difficulty of producing a cost-effective compliant waste form for storage.

Most of the research that has been reported addresses microencapsulation of powdered wastes; limited research has been performed on macroencapsulation. This is due to the fact that there are more risks associated with microencapsulation, e.g., leachability, degradation, and potential for chemical interaction between the polymer binder and the fine wastes. The primary concerns for macroencapsulation are the durability of the encapsulating polymer and the potential for stress 
fracture. Because macroencapsulation is the encapsulation of a bulk waste such as lead debris, leaching and chemical interaction with the solid waste are not of concern.

Although polymer encapsulation is not as widely used as cementation, polymers offer several advantages over the typical cement encapsulation processes. The most important advantages are the increased waste loadings, the increased durability of the waste form, and the relative insensitivity to variations in the waste stream chemistry. These advantages also make it possible for polymer encapsulation, particularly polyethylene, to provide an overall treatment cost savings. The increased waste form durability is a result of the fact that polyethylene is highly resistant to biodegradation, attack by aggressive chemicals, and radiation doses. In fact, radiation doses through $10^{8}$ rad increase the crosslinking and improve strength and other physical properties of polyethylene (Kalb et al., 1993). Other advantages include: it has passed all EPA and NRC tests for compressive strength and leachability; the fact that it is an off-the-shelf technology where all of the equipment and materials are already available from private vendors; the technology is relatively simple; it is a non-thermal treatment process and therefore no secondary waste streams are produced; the polymer industry has decades of experience in polymer processing; and it provides a market for recycled polymers.

The only disadvantage of this technology is, at this point in time, no pilot- or full-scale tests have been performed using polyethylene encapsulation to treat actual low-level mixed waste streams. All tests have been conducted with surrogates. Faucette (1996) notes that extended hot pilot-scale tests using actual waste streams were planned for 1996 and results should soon be forthcoming.

If the "hot" tests with actual waste streams at RFETS yield successful results and given the favorable results summarized in this report, polymer encapsulation of low-level mixed wastes should be strongly considered for treatment of wastes from the Nevada Test Site.

\section{REFERENCES}

Armentrout, D.L. and A.M. Faucette, 1996. Polymer microencapsulation of low level mixed bypass sludge. A Final Report, Rocky Mountain Remediation Services, TI-96-014, 29p.

Environmental Protection Agency, 1990. Toxicity characteristic leaching procedure (TCLP), 40 CFR 21, Appendix II, Federal Reg. 55:11863, March 29.

Bikales, N.M., ed., 1967. Ethylene polymers. Encyclopedia of Polymer Science and Technology, Interscience Publishers, New York, Vol. 6, p. 275.

Faucette, A.M., 1996. Polymer Encapsulation. A chapter submitted to the DOE Office of Technology Development Rainbow Books.

Franz, E.M. and P. Colombo, 1984. Waste form evaluation program, Final Report. Brookhaven National Laboratory, BNL 51954, September.

Franz, E.M., J.H. Heiser, and P. Colombo, 1987. Solidification of problem wastes, Annual Progress Report. Brookhaven National Laboratory, BNL 52078, February. 
Heiser, J.H., E.M. Franz, and P. Colombo, 1989. A process for solidifying sodium nitrate waste in polyethylene. In, Environmental Aspects of Stabilization and Solidification of Hazardous and Radioactive Wastes, ASTM STP 1033, P. Cote and M. Gilliam, eds., American Society for Testing and Materials, Philadelphia.

Kalb, P.D. and P. Colombo, 1984. Polyethylene solidification of low-level wastes. A Topical Report, Brookhaven National Laboratory, BNL 51867, 65p.

Kalb, P.D., M. Fuhrmann and P. Colombo, 1993. Polyethylene Encapsulation of Single Shell Tank Low-Level Wastes. In, Technology and Programs for Radioactive Waste Management and Environmental Restoration, Vol 2, Brookhaven National Laboratory, BNL-48607.

Kalb, P.D., J.H. Heiser, and P. Colombo, 1993. Long-term durability of polyethylene for encapsulation of low-level radioactive, hazardous, and mixed wastes. In, Emerging Technologies in Hazardous Waste Management III, American Chemical Society, pp. 439-449.

Kalb, P.D., J.H. Heiser, and P. Colombo, 1991a. Modified sulfur cement encapsulation of mixed waste contaminated incinerator fly ash. Waste Management, 11:147-153.

Kalb, P.D., J.H. Heiser, and P. Colombo, 1991b. Polyethylene encapsulation of nitrate salt wastes: waste form stability, process scale-up, and economics. A Technology Status Topical Report, Brookhaven National Laboratory, BNL 52293, 73p.

Kalb, P.D. and P.R. Lageraaen, 1994. Polyethylene encapsulation full-scale technology demonstration. A Final Report, Brookhaven National Laboratory, BNL-52478, 36p.

Raff, R.A.V. and J.B. Allison, 1956. Polyethylene. Interscience Publishers, New York.

Roach, J. 1996. Mixed waste focus area. A Technology Development Requirements Document, Idaho National Engineering Laboratory, 15p. 


\section{APPENDIX A}

THE APPLICATION OF POLYETHYLENE RESINS IN VARIOUS CHEMICAL ENVIRONMENTS ${ }^{a}$ (from Kalb et al., 1991b).

\begin{tabular}{|c|c|c|}
\hline \multirow[b]{2}{*}{ Chemical } & \multicolumn{2}{|c|}{ Polyethylene can be used at } \\
\hline & $25^{\circ} \mathrm{C}$ & $60^{\circ} \mathrm{C}$ \\
\hline Acetic Acid (10 wt\%) & Yes & Yes \\
\hline Acetic Acid (Glacial) & No & No \\
\hline Acetone & Yes & No \\
\hline Alcohol, benzyl & No & No \\
\hline Alcohol, ethyl (35 wt\%) & No & No \\
\hline Alcohol, methyl & No & No \\
\hline Alcohol, propyl & No & No \\
\hline Aluminum chloride & Yes & Yes \\
\hline Aluminum fluoride & Yes & Yes \\
\hline Aluminum hydroxide & Yes & Yes \\
\hline Aluminum sulfate & Yes & Yes \\
\hline Ammonia & Yes & Yes \\
\hline Ammonium carbonate & Yes & Yes \\
\hline Ammonium chloride & Yes & Yes \\
\hline Ammonium hydroxide (28 wt\%) & Yes & Yes \\
\hline Ammonium nitrate & Yes & Yes \\
\hline Ammonium persulfate & Yes & Yes \\
\hline Ammonium phosphate (75 wt\%) & Yes & Yes \\
\hline Ammonium sulfate & Yes & Yes \\
\hline Amyl acetate & No & No \\
\hline Aqua regia & No & No \\
\hline Barium carbonate & Yes & Yes \\
\hline Barium chloride & Yes & Yes \\
\hline Barium sulfate & Yes & Yes \\
\hline Barium sulfide & Yes & Yes \\
\hline Benzene & No & No \\
\hline Boric acid & Yes & Yes \\
\hline Calcium carbonate & Yes & Yes \\
\hline Calcium chlorate & Yes & Yes \\
\hline Calcium chloride & Yes & Yes \\
\hline Calcium hydroxide & Yes & Yes \\
\hline Calcium hypochlorite & Yes & No \\
\hline Calcium sulfate & Yes & Yes \\
\hline Carbon dioxide, dry gas & Yes & Yes \\
\hline Carbon monoxide & Yes & Yes \\
\hline
\end{tabular}




\begin{tabular}{|c|c|c|}
\hline \multirow[b]{2}{*}{ Chemical } & \multicolumn{2}{|c|}{ Polyethylene can be used at } \\
\hline & $25^{\circ} \mathrm{C}$ & $60^{\circ} \mathrm{C}$ \\
\hline Carbon tetrachloride & No & No \\
\hline Carbonic acid & Yes & Yes \\
\hline Chlorine gas, wet or dry & No & No \\
\hline Chromic acid ( 80 wt\%) & Yes & Yes \\
\hline Citric acid & Yes & Yes \\
\hline Copper chloride & Yes & Yes \\
\hline Copper cyanide & Yes & Yes \\
\hline Copper nitrate & Yes & Yes \\
\hline Copper sulfate & Yes & Yes \\
\hline Ethylene glycol & Yes & Yes \\
\hline Ferric chloride & Yes & Yes \\
\hline Ferric nitrate & Yes & Yes \\
\hline Ferric sulfate & Yes & Yes \\
\hline Ferrous chloride & Yes & Yes \\
\hline Ferrous sulfate & Yes & Yes \\
\hline Fertilizers & Yes & Yes \\
\hline Fluorine & No & No \\
\hline Formaldehyde (40 wt\%) & Yes & Yes \\
\hline Formic acid & Yes & Yes \\
\hline Gasoline & No & No \\
\hline Glycerine & Yes & Yes \\
\hline Hydrochloric acid & Yes & Yes \\
\hline Hydrofluoric acid (48 wt\%) & Yes & Yes \\
\hline Hydrogen peroxide ( 3 wt\%) & Yes & Yes \\
\hline Hydrogen peroxide (90 wt\%) & Yes & No \\
\hline Hydrogen sulfide, dry gas & Yes & Yes \\
\hline Lead acetate & Yes & Yes \\
\hline Lubricating oil & No & No \\
\hline Magnesium carbonate & Yes & Yes \\
\hline Magnesium chloride & Yes & Yes \\
\hline Magnesium hydroxide & Yes & Yes \\
\hline Magnesium nitrate & Yes & Yes \\
\hline Magnesium sulfate & Yes & Yes \\
\hline Mercuric chloride & Yes & Yes \\
\hline Mercurous nitrate & Yes & Yes \\
\hline Mercury & Yes & Yes \\
\hline Methyl chloride & No & No \\
\hline Methyl ethyl ketone & No & No \\
\hline Mixed acids & Yes & No \\
\hline
\end{tabular}




\begin{tabular}{|c|c|c|}
\hline \multirow[b]{2}{*}{ Chemical } & \multicolumn{2}{|c|}{ Polyethylene can be used at } \\
\hline & $25^{\circ} \mathrm{C}$ & $60^{\circ} \mathrm{C}$ \\
\hline Nickel chloride & Yes & Yes \\
\hline Nickel nitrate & Yes & Yes \\
\hline Nickel sulfate & Yes & Yes \\
\hline Nitric acid (10 wt\%) & Yes & Yes \\
\hline Nitric acid (50 wt\%) & Yes & No \\
\hline Nitric acid (95 wt\%) & No & No \\
\hline Nitric acid vapors & Yes & Yes \\
\hline Oxidizing gases & Yes & Yes \\
\hline Ozone & No & No \\
\hline Perchloric acid & Yes & Yes \\
\hline Phenol (94 wt\%) & Yes & No \\
\hline Phosphoric acid (30 wt\%) & Yes & Yes \\
\hline Phosphoric acid ( 85 wt\%) & Yes & No \\
\hline Picric acid & Yes & No \\
\hline Potassium bicarbonate & Yes & Yes \\
\hline Potassium borate & Yes & Yes \\
\hline Potassium bromide & Yes & Yes \\
\hline Potassium carbonate & Yes & Yes \\
\hline Potassium chlorate & Yes & Yes \\
\hline Potassium dichromate (40 wt $\%$ ) & Yes & Yes \\
\hline Potassium hydroxide & Yes & Yes \\
\hline Potassium nitrate & Yes & Yes \\
\hline Potassium permanganate ( $95 \mathrm{wt} \%$ ) & Yes & Yes \\
\hline Potassium sulfate & Yes & Yes \\
\hline Silver nitrate & Yes & Yes \\
\hline Sodium acetate & Yes & Yes \\
\hline Sodium benzoate & Yes & Yes \\
\hline Sodium bicarbonate & Yes & Yes \\
\hline Sodium bisulfate & Yes & Yes \\
\hline Sodium bisulfite & Yes & Yes \\
\hline Sodium bromide & Yes & Yes \\
\hline Sodium carbonate & Yes & Yes \\
\hline Sodium chloride & Yes & Yes \\
\hline Sodium cyanide & Yes & Yes \\
\hline Sodium fluoride & Yes & Yes \\
\hline Sodium hydroxide & Yes & Yes \\
\hline Sodium hypochlorite & Yes & No \\
\hline Sodium nitrate & Yes & Yes \\
\hline
\end{tabular}




\begin{tabular}{lcc}
\hline \multicolumn{1}{c}{ Chemical } & \multicolumn{2}{c}{ Polyethylene can be used at } \\
& $25^{\circ} \mathrm{C}$ & $60^{\circ} \mathrm{C}$ \\
\hline Sodium nitrite & Yes & Yes \\
Sodium sulfate & Yes & Yes \\
Sodium sulfide & Yes & Yes \\
Sodium sulfite & Yes & Yes \\
Stannous chloride & Yes & Yes \\
Stearic acid & Yes & Yes \\
Sulfur & Yes & Yes \\
Sulfur dioxide & Yes & Yes \\
Sulfuric acid $(50 \mathrm{wt} \%)$ & Yes & Yes \\
Sulfuric acid $(70 \mathrm{wt} \%)$ & Yes & No \\
Sulfuric acid $(96 \mathrm{wt} \%)$ & No & No \\
Tannic acid $(10 \mathrm{wt} \%)$ & Yes & Yes \\
Toluene & No & No \\
Transformer oils & No & No \\
Trichloroethylene & No & No \\
Trisodium phosphate & Yes & Yes \\
Vegetable oil & No & No \\
Water, distilled & Yes & Yes \\
Xylene & No & No \\
Zinc chloride & Yes & Yes \\
Zinc sulfate & Yes & Yes \\
\hline Adapted & & \\
\hline
\end{tabular}

aAdapted from Raff and Allison, 1956. 


\section{DISTRIBUTION}

Bob Bangerter

Environmental Restoration Division

Nevada Operations Office

U.S. Department of Energy

P.O. Box 98518

Las Vegas, NV 89193-8518

Joanne M. Bradbery, Director

Contract Management Division

Nevada Operations Office

U.S. Department of Energy

P.O. Box 98518

Las Vegas, NV 89193-8518

David Bedsun

Defense Special Weapons Agency

Field Command

Nevada Operations Office

P.O. Box 208

Mercury, NV 89023-0208

Mary Lou Brown

International Technology Corporation 4330 S. Valley View

Suite 114

Las Vegas, NV 89103

James Cebe

Energy Technologies Division

Nevada Operations Office

U.S. Department of Energy

P.O. Box 98518

Las Vegas, NV 89193-8518

Beverly Colbert

Contract Management Division

Nevada Operations Office

U.S. Department of Energy

P.O. Box 98518

Las Vegas, NV 89193-8518

Frank Di Sanza, Director

Energy Technologies Division

Nevada Operations Office

U.S. Department of Energy

P.O. Box 98518

Las Vegas, NV 89193-8518
Brian Dozier

Bechtel Nevada Corporation

P.O. Box 98521

Las Vegas, NV 89193-8521

Doug Duncan

Hydrology Program Manager

Environmental Protection Division

Nevada Operations Office

U.S. Department of Energy

P.O. Box 98518

Las Vegas, NV 89193-8518

Dennis Farmer

Radiation Sciences Laboratory

Office of Radiation and Indoor Air

U.S. Environmental Protection Agency

P.O. Box 98517 , M/S 513

Las Vegas, NV 89193-8517

Larry Franks

Nevada State Health Department

Radiological Health Section

620 Belrose Avenue

Las Vegas, NV 89158

Joseph M. Ginanni

Waste Management Division

Nevada Operations Office

U.S. Department of Energy

P.O. Box 98518

Las Vegas, NV 89193-8518

Kenneth Hoar, Director

Environmental Protection Division

Nevada Operations Office

U.S. Department of Energy

P.O. Box 98518

Las Vegas, NV 89193-8518

Kathy Izell

Assistant Manager for Technical Services

Nevada Operations Office

U.S. Department of Energy

P.O. Box 98518

Las Vegas, NV 89193-8518 
Roger Jacobson

Desert Research Institute

Water Resources Center

P.O. Box 19040

Las Vegas, NV 89132-0040

Marjory Jones

Desert Research Institute

Water Resources Center

P.O. Box 60220

Reno, NV 89506-0220

Jim Kannard

Bechtel Nevada Corporation

P.O. Box 98521

Las Vegas, NV 89193-8521

Randy Laczniak

U.S. Geological Survey

Water Resources Division

6770 S. Paradise Rd.

Las Vegas, NV 89119

Steve Lawrence

Engineering Division

Nevada Operations Office

U.S. Department of Energy

P.O. Box 98518

Las Vegas, NV 89193-8518

Steve Leedom

Stockpile Stewardship Division

Nevada Operations Office

U.S. Department of Energy

P.O. Box 98518

Las Vegas, NV 89193-8518

Charles E. McWilliam, Director

Defense Projects Division

Nevada Operations Office

U.S. Department of Energy

P.O. Box 98518

Las Vegaś, NV 89193-8518
Steve Mellington, Director

Environmental Restoration Division

Nevada Operations Office

U.S. Department of Energy

P.O. Box 98518

Las Vegas, NV 89193-8518

Leslie A. Monroe

Environmental Protection Division

Nevada Operations Office

U.S. Department of Energy

P.O. Box 98518

Las Vegas, NV 89193-8518

Colleen O'Laughlin

Energy Technologies Division

Nevada Operations Office

U.S. Department of Energy

P.O. Box 98518

Las Vegas, NV 89193-8518

Ken Rehfeldt

Geotrans, c/o IT

4330 Valley View

Suite 112, MS-439

Las Vegas, NV 89103

Stuart E. Rawlinson

Bechtel Nevada Corporation

P.O. Box 95487 , M/S 580

Las Vegas, NV 89193-5487

Monica Salazar-Sanchez

Environmental Restoration Division

Nevada Operations Office

U.S. Department of Energy

P.O. Box 98518

Las Vegas, NV 89193-8518

Ralph Smiecinski

Energy Technologies Division

Nevada Operations Office

U.S. Department of Energy

P.O. Box 98518

Las Vegas, NV 89193-8518

David K. Smith

Isotopes Sciences Division

Lawrence Livermore National Laboratory

P.O. Box 808, M/S L231

Livermore, CA 94550 
Michael J. Sully

Bechtel Nevada Corporation

P.O. Box 98521, M/S 966

Las Vegas, NV 98193-8521

Joe Thompson

Los Alamos National Laboratory

INC-11, MS J514

P.O. Box 1663

Los Alamos, NM 87545

Doug Trudeau

U.S. Geological Survey

Water Resources Division

6770 S. Paradise Rd.

Las Vegas, NV 89119

Janet Wiley

International Technology Corporation 4330 S. Valley View

Suite 114

Las Vegas, NV 89103

\section{Annie Kelley}

State Documents Department

Nevada State Library

Capitol Complex

Carson City, NV 89710

Archives

Getchell Library

University of Nevada, Reno

Beverly Carter

MacKay School of Mines Library

University of Nevada, Reno

Document Section, Library

University of Nevada, Las Vegas

4505 Maryland Parkway

Las Vegas, NV 89154
Library (Stead)

Desert Research Institute

P.O. Box 60220

Reno, Nevada 89506-0220

Library

IT Corporation

4330 S. Valley View

Suite 114

Las Vegas, NV 89103

ATTN: Toni Miller

Library

Southern Nevada Science Center

Desert Research Institute

P.O. Box 19040

Las Vegas, NV 89132-0040

Public Reading Facility

Bechtel Nevada Corporation

P.O. Box 98521

Las Vegas, NV 89193-8521

Technical Information Resource Center

Nevada Operations Office

U.S. Department of Energy

P.O. Box 98518

Las Vegas, NV 89193-8518

Librarian

Water Resources Center Archives

410 O'Brien Hall

University of California

Berkeley, CA 94720-1718

Office of Scientific and Technical Information

U.S. Department of Energy

P.O. Box 62

Oak Ridge, TN 37831-9939 